\title{
Does political community require public reason? On Lister's defence of political liberalism
}

\author{
Paul Billingham (University of Oxford, UK) \\ paul.billingham@politics.ox.ac.uk
}

This is an Accepted Manuscript version of an article published in Politics, Philosophy \& Economics. Published version available here: http://ppe.sagepub.com/content/15/1/20.

\begin{abstract}
Andrew Lister's Public Reason and Political Community is an important new contribution to the debate over political liberalism. In this article I critically evaluate some of the central arguments of the book, in order to assess the current state of public reason liberalism. I pursue two main objections to Lister's work. First, Lister's justification for public reason, which appeals to the value of civic friendship, fails to show why public reason liberalism should be preferred to an alternative democratic theory that does not include public reason restrictions. Second, there are several important ambiguities and tensions within Lister's view that he does not adequately resolve. His approach to them often takes public reason liberalism in directions that many of its advocates will reject. More work thus remains to be done by public reason liberals both to show why public reason restrictions are necessary and to resolve these tensions in a more satisfactory way.
\end{abstract}

\section{Keywords}

civic friendship; deliberative democracy; Andrew Lister; political liberalism; public reason

\section{Introduction}

Andrew Lister's Public Reason and Political Community (2013) is an important new contribution to the debate over public justification and public reason. Lister draws several distinctions that will be invaluable in future writing on this topic, and offers a distinctive justification for public reason, based on it being necessary if citizens are to have relationships of civic friendship. I outline that argument in the next section, before pursuing two lines of critique. First, in Section 3, I argue that Lister has not successfully 
shown that his understanding of democratic political community is superior to an alternative model, which does not include public reason restrictions. Second, in Section 4, I discuss several ambiguities and tensions within public reason liberalism that Lister has not adequately resolved. Lister's theory can better respond to certain familiar objections to the view, but also threatens to weaken public reason in a way that many of its advocates will reject, and that further reduces the distance between his view and the alternative model discussed in Section 3. Those who embrace that alternative are thus given little reason to change their mind, and those who favour public reason will need to find other justifications for that ideal, and other ways to resolve tensions within public reason theory.

\section{Lister's defence of public reason}

\subsection{Two types of political liberalism}

In Chapter 1 of Public Reason and Political Community, Lister (2013: 15-23) helpfully distinguishes between two very different approaches to the public justification principle (PJP) that lies at the heart of political liberalism. PJP states that 'we should exercise political power only in ways it is reasonable to expect everyone to accept' (Lister, 2013: 8). According to the 'reasons-for-decisions frame', this means that political decisions must be justifiable in terms of unanimously acceptable reasons. There is a certain class of reasons that are acceptable to all reasonable citizens, and these must be used to justify political institutions and policies. Reasons that are not acceptable to all are 'non-public', so excluded from our decision-making. According to the alternative interpretation of PJP, the 'coercion frame', it is coercive institutions and laws themselves that must be unanimously acceptable, on the basis of whatever reasons each (reasonable) citizen accepts. Laws that are not acceptable to all must not be enacted, leaving us at the default of inaction.

Advocates of the former, reasons-for-decisions, interpretation include John Rawls (2005) and Jonathan Quong (2011), while Gerald Gaus $(2009,2010,2011)$ is the most prominent defender of the coercion frame. ${ }^{1}$ Many theorists have failed to make this distinction, however, so have been unclear as to which interpretation of PJP they are defending or objecting to. As Lister shows, whether one takes PJP to be 
about the unanimous acceptability of the reasons used to justify coercion or of coercion itself makes a significant difference to the implications of political liberalism. For example, the coercion frame makes room for 'convergence justifications', where citizens all accept a law but for different reasons, while the reasons-for-decisions frame only permits 'consensus justifications', where citizens share reasons for the law (Lister, 2013: 17-8). ${ }^{2}$ Further, different objections apply to the different interpretations of PJP, and different arguments are needed to justify them. It is therefore crucial that theorists make it clear which view they are discussing. In this article, I will use 'justificatory liberalism' to refer to theories endorsing the coercion frame, and 'public reason liberalism' to refer to theories that endorse the reasons-for-decisions frame. Both are variants of 'political liberalism', which refers to any theory based on PJP. Lister's argument for political liberalism, to which I now turn, is explicitly intended to support public reason liberalism. ${ }^{3}$

\subsection{Civic friendship and public reason}

Like most political liberals, Lister starts with the fact of reasonable pluralism - the fact that modern liberal societies are characterised by deep yet reasonable disagreement over religious, moral, and philosophical questions (Rawls, 2005: 36-7). This makes comprehensive conceptions of the good inappropriate grounds for political action. The specific reason it does so in Lister's view, however, is not that restraint from appeal to comprehensive reasons is necessary for the sake of freedom of conscience, democracy, anti-paternalism, or respect for persons. ${ }^{4}$ Instead, it is because 'the joint commitment to making political decisions on public grounds realises a valuable kind of relationship' (Lister, 2013: 106). 'Public reason makes possible civic friendship despite deep disagreement' (Lister, 2013: 105).

Schwarzenbach $(1996,2005)$ has argued that civic friendship is vital to modern liberal democracies. The idea that it plays a role in justifying political liberalism is hinted at by Rawls (2005: 447) and has been further developed by Ebels-Duggan (2010). Lister presents a distinctive and sophisticated version of this argument.

Public reasons are ones that all reasonable citizens can recognise as having normative force, whatever 
their conception of the good. They are reasons arising from values and principles that all such citizens share - values that are beyond reasonable rejection. When laws are made on the basis of such reasons, this guarantees that no-one 'can reasonably think that the collectivity's decisions aim at fundamentally alien values' (Lister, 2013: 106). Each can recognise the grounds of laws as ones they share with all other reasonable citizens, and this realises a valuable form of community. The mutual performance of the duty of civility - every citizen basing their political action on public reasons - constitutes citizens' relationships as ones of civic friendship. Making political decisions on non-public grounds, on the other hand, 'is inconsistent with citizens having the right kind of relationship' (Lister, 2013: 116).

Importantly, civic friendship does not require that all citizens consider political decisions to be the best decisions, or conclusively justified. Many will believe that laws are sub-optimal, on the basis of their comprehensive doctrine. Some will also believe that laws fail to accurately reflect the balance of public reasons. There is a wide range of values and principles that all can reasonably be expected to endorse, and their interpretation, relative weighting, and application to particular policy issues will be controversial (Lister, 2013: 17, 102). Citizens will thus disagree on which laws are most supported by the balance of public reasons. Democratic deliberation and decision-making procedures will be needed to enact laws. Nonetheless, as long as political decisions can be justified by public reasons, and citizens and officials base their own reasoning and advocacy on such reasons, civic friendship is realised. Each can recognise the commitment of all to base their collective decisions and shared actions on considerations all can accept, even when they disagree over the interpretation of those considerations. All have demonstrated a willingness to set aside reasons and values over which there is deep disagreement, and to act based solely on values that all recognise as having normative force. Those in the minority in a democratic vote will believe that the wrong decision has been made, even solely based on public reasons, but can nonetheless accept the values and principles grounding that decision, and recognise that others have sought to base the decision on shared values. A valuable form of community is thereby realised: a political association animated by purposes that none consider alien. 
Citizens' willingness to live with laws they consider sub-optimal from their comprehensive perspective is in fact part of how public reason realises civic friendship. Each bears a moral cost in agreeing to set aside comprehensive considerations and act on the basis of public reasons. For many, this will mean that what they consider to be full justice cannot be achieved, since it is not justifiable using public reasons. They give up this ideal for the sake of their ongoing cooperative relationship with other citizens (Lister, 2013: 109). Public reason is a moral compromise, with each bearing a moral cost in order to achieve the great good of civic friendship (Lister, 2013: 116-120).

This argument clearly supports public reason liberalism, rather than justificatory liberalism. Indeed, Lister's view permits the enactment of laws that justificatory liberals would consider illegitimate - laws that are plausibly justified by public reasons but that some citizens reject, based on the full set of reasons that they accept (Lister, 2013: 18). ${ }^{5}$ For Lister, civic friendship is realised in these cases, since the laws are justified by reasons all can accept. For justificatory liberals, however, such laws disrespect the citizens whose broader worldviews, or alternative view of the balance of public reasons, give them decisive reasons to reject the laws. These laws are not justified to these citizens, so should not be enacted (Gaus, 2010: 195-6).

Lister adeptly summarises his view in his Conclusion (Lister, 2013: 175):

Public reason provides a basis for community in a pluralistic democracy. The commitment to public justification constitutes a relation of civic friendship between persons deeply divided by conflicting religious and philosophical points of view.

It is the willingness to make decisions on the basis of grounds that all can reasonably be expected to accept despite the moral cost this may entail from one's own comprehensive perspective that constitutes the relationship of civic friendship.

\section{Competing models of political community}

\subsection{Argumentative democracy}

Lister's justification for public reason liberalism on grounds of civic friendship immediately invites the 
question of whether there are any alternative models of political community that do not include public reason requirements, yet might also realise valuable relationships between citizens. One obvious alternative is an understanding of deliberative democracy with three central features. First, citizens openly and honestly deliberate with one another, seeking to understand and respond to each other's reasons and arguments, while being open to persuasion. Second, decisions are made using democratic procedures, with citizens voting on the basis of their best judgment of the overall balance of reasons. Third, there are no restrictions on the reasons, values, or principles that citizens are permitted to appeal to in public deliberation, and to base their votes on.

Nicholas Wolterstorff's (2012) understanding of 'liberal democracy as equal political voice' is an example of this view. Every citizen has an equal right to full participation in political decision-making, all viewpoints are heard and respected, and citizens then vote based on their all-things-considered judgment of what laws are best. Similarly, Christopher Eberle (2002: 84-108) defends an 'ideal of conscientious engagement', according to which citizens are obligated to seek rational justification for laws they advocate and to engage with the perspectives of others, seeking to offer them reasons for laws that they find persuasive, but are ultimately free to vote for whatever laws they favour, for whatever reasons they consider sufficient. I will refer to this as 'argumentative democracy'.

Both Wolterstorff and Eberle claim that argumentative democracy realises valuable relationships between citizens. Each citizen commits to understanding others' points of view, and to engaging in public deliberation as to what decisions best promote justice and the common good. Each takes the arguments that others present seriously, and seeks to grapple with those arguments and present defences of her own views. Citizens also recognise that the views of each person matter equally, such that decisions should be made democratically, giving each an equal vote and an equal influence over outcomes. These practices are rightly seen as embodying many important aspects of mutual respect, and realising certain goods of friendship and community. Lister is mistaken in suggesting that only public reason liberalism enables citizens to have 'a relationship of mutual respect across deep differences' (Lister, 2013: 130). 
The important question, therefore, is whether the kind of community created by argumentative democracy is less valuable than public-reason-based civic friendship. Lister's justification for public reason liberalism draws us into this comparison between alternative models of political community.

\subsection{Alien values}

Lister emphasises that public reason liberalism guarantees that no-one can reasonably think that society's decisions aim at values they find fundamentally alien. He would argue that this achieves a more valuable form of political community than argumentative democracy, where laws might well be enacted for which the only supporting reasons are ones that some citizens see as having no normative force at all (Lister, 2013: 120).

In considering this argument, it is important to recognise that argumentative democracy does not simply allow one group in society to impose their comprehensive doctrine upon others. Basic rights - to freedom of conscience, religion, speech, association, and so on - should be given constitutional protection. Wolterstorff and Eberle defend liberal democracy. While religious citizens can base their advocacy and votes on religious reasons, they are not permitted to force others to convert to their religion, or to stop others from practising their own religion. Earlier in his book, Lister $(2013,29-35)$ rightly argues that questions of freedom of religion, and by extension the protection of other basic rights, are independent of the public reason debate.

Designing a law or institution on the basis of some reason $\mathrm{X}$ does not necessarily imply forcing people to believe $X$, denying them the right to speak against $X$, or giving proponents of $X$ more resources... Not just any decision made on the basis of a religious reason involves the attempt to shift the distribution of belief in favour of this reason. Policies motivated by religious reasons may simply aim at what is right, in the eyes of those with the views in question. (Lister, 2013: 32-3)

We should also note that argumentative democracy still incentivises the use of shared values. Citizens seeking to persuade others to support laws will often appeal to principles and values they share. There are 
clear pragmatic reasons for doing this, since citizens are unlikely to persuade others or create the majority needed for laws to be enacted if they merely offer comprehensive reasons. It is also likely that in many cases a citizen's comprehensive doctrine will not directly bear upon a law, or will provide reasons for her to accept certain political principles that are also accepted by those with other comprehensive doctrines. Any stark contrast between political action based on 'shared values' and on 'diverse comprehensive doctrines' is overdrawn. ${ }^{7}$

The relevant comparison is therefore between two societies where there is a constitution protecting basic liberal rights, and laws are then enacted through democratic processes, where each citizen has (a right to) an equal voice and vote, but in one polity citizens comply with public reason restrictions and in the other they do not. In neither society are all forced to comply with the religion of some, and shared values and principles will be appealed to in both. In the latter polity, however, laws can also be enacted by a majority of citizens on the basis of reasons drawn from their (likely diverse) comprehensive doctrines. The question is whether relationships between citizens are in some way superior in the society where political advocacy is based on public reasons. Lister needs to give an affirmative answer to this question in order for his argument for public reason liberalism to succeed. The alien values objection to argumentative democracy is one way to justify that affirmative answer.

The alien values objection is based on the fact that argumentative democracy allows a religious majority (or a coalition of citizens with different comprehensive doctrines) to enact laws for which their only justifications are comprehensive reasons. While these laws cannot enforce a religion, in the sense of forcing all citizens to practice its religious rituals, they can force all citizens to comply with moral requirements that only have a religious justification. Abortion laws might be justified by an appeal to a religiously-grounded stance on the bounds of moral status, or religious reasons might be used to defend a particular view of distributive justice that cannot be justified using public reasons. As Lister (2013: 33) argues, such laws do not impose a religion; they simply are laws justified by religious reasons. Nonetheless, he would assert that these laws promote values that are alien to some citizens, so prevent 
civic friendship. ${ }^{8}$ Under public reason liberalism, in contrast, every reasonable member of the polity can see it as acting in view of common goals, so the group is a collective agent in a richer sense than mere argumentative democracy allows (Lister, 2013: 113-4).

Argumentative democracy is itself based upon a set of shared commitments that enable citizens to realise a valuable form of community, however. Citizens should be committed to acting together based on democratic decisions, to subjecting their views to critical scrutiny, to seeking points of common cause with one another wherever they can be found, and to each supporting what they believe to be the best laws those that best serve true justice and the common good. Citizens give one another equal political voice despite believing that many have false views. In this way, they are committed to acting together despite their disagreements, as equal members of the political community, and develop a sense of shared identity and social unity. In other words, they enjoy civic friendship. ${ }^{9}$

It is still possible that values I consider deeply mistaken might be pursued within argumentative democracy in a way that they cannot be in public reason liberalism. If civic friendship was measured merely by how much shared ground there is between citizens then this would show that it is enjoyed to a greater extent in public reason liberalism than in argumentative democracy. But Lister's understanding of civic friendship focuses on the commitment that citizens have to acting together despite disagreements, even when this constrains the achievement of comprehensive philosophical objectives, and on the associated attitudes of mutual respect. This cannot be measured simply by how much citizens share. It is instead concerned with how citizens respond to the fact that they disagree on so much. On this understanding, citizens within argumentative democracy do enjoy civic friendship.

This is the case because the commitments and attitudes that Lister believes to be constitutive of civic friendship are present in argumentative democracy. In a polity where citizens' basic rights are secured and laws are made through deliberative democratic processes, citizens engage in a shared enterprise, with the shared purpose of living under the resulting laws. Even when the only substantive justification for laws 
appeals to values or beliefs I reject, I can still recognise that laws were enacted via a process of deliberation and democratic decision-making in which I participated as an equal citizen. I can appreciate that my compatriots listened to my arguments, sought to persuade me of their views, and acted in good faith on the basis of what they consider to be the best reasons. Wolterstorff and Eberle would even argue that a truer form of civic friendship is achieved here than under public reason liberalism, since citizens openly engage with all of one another's reasons and beliefs, including their comprehensive ones. ${ }^{10}$ Even if we do not go that far, further argument is needed for why setting aside controversial reasons and acting only on shared ones enables a more valuable kind of relationship than is achieved under argumentative democracy. The alien values objection cannot secure that conclusion, given Lister's conception of civic friendship. Citizens within argumentative democracy enjoy civic friendship in his sense. ${ }^{11}$

\subsection{Counterfactual assurance}

Lister follows Rawls in arguing that a central problem with modus vivendi arrangements is a lack of counterfactual assurance. Even if the modus vivendi is currently stable, all know that if one group in society became dominant then they would impose their comprehensive doctrine upon everyone (Rawls, 2005: 146-7). This affects the nature of citizens' relationships with one another. The concern is not merely with security, in the sense of avoiding bad outcomes, since the counterfactual situations might be very unlikely, and never arise. Instead, the idea is that mutual knowledge of what would happen if they did arise detrimentally affects the quality of citizens' relationships here and now. 'Common knowledge of this counterfactual instability would mean that citizens have to regard one another as enemies not to be trusted without the security of threats of sanctions or reprisals, not as common participants in a cooperative endeavour' (Lister, 2013: 115).

This is not true in the case of a principled liberal argumentative democracy, however. Citizens in this model are committed to the cooperative endeavour of basing their common life on decisions made through deliberative democratic processes. Even if the balance of power in society shifted, this would not lead the newly powerful group to violate liberal rights or force everyone to practice their religion. 
Lister (2013: 115) recognises this, and says that citizens will not have the same kind of distrust when laws are made based on the overlap of citizens' comprehensive doctrines as they do in mere modus vivendi. Nonetheless, he claims that counterfactual assurance is low in this situation, since all know that others would cease to support their current laws and institutions if their assessment of their comprehensive doctrines changed. Citizens are participants in a common project only contingent on their comprehensive doctrines happening to overlap. He contrasts this with the situation under public reason: 'A shared commitment to public reason involves mutual recognition that our support for the measures in question is not contingent on the details of the various comprehensive doctrines we accept, but instead, represents a common desire to live according to terms of cooperation that all could reasonably accept' (Lister, 2013: 115-6).

This comparison is mistaken, however. Under argumentative democracy, changes in the balance of comprehensive beliefs within society might well lead to changes in the law, with more laws being enacted through appeal to the newly-prominent doctrine(s). Similarly, changes in citizens' understanding of their comprehensive doctrines will lead to laws changing. Any such changes will occur democratically, and all citizens are still partners in a common political project - just one that now involves different laws. The particular laws that a polity has will depend on the beliefs and values of its citizenry, but there is a stable common desire to live under democratically enacted laws.

The same is true under public reason liberalism. Support for particular laws is contingent on the specific details of citizens' views on the interpretation and relative weighting of the shared values within public reason. These views can change over time, leading to changes in law. Such changes in citizens' understandings of the balance of public reason might in part be due to changes in their comprehensive doctrine, which inevitably influences that understanding to some degree (see Greenawalt 1988). Some might find the resulting changes in law unfortunate, since they consider the old laws to better reflect public reason, or to be closer to ideal justice. This does not stop these citizens recognising others' 
continued commitment to public reason, however. There is a stable common desire to live under laws justified by public reasons.

The situation under the two theories is thus equivalent. Further, we have no reason to believe that the desire to live under democratically enacted laws will be any less stable than the commitment to public reason. In both cases, some will undoubtedly reject the relevant account of legitimacy, and thus be deemed unreasonable by the theory. And in both cases this will occur due to citizens' comprehensive doctrines conflicting with the account. Both models ultimately rest on their being supported by comprehensive doctrines within society.

In Lister's model, each reasonable citizen knows that all reasonable citizens are committed to making decisions based on public reasons, so will continue to do so even if the balance of comprehensive doctrines in society changes. In Wolterstorff's model, each reasonable citizen knows that all reasonable citizens are committed to making decisions using deliberative democratic procedures, so will continue to do so even if the balance of comprehensive doctrines in society changes. This marks both out from mere modus vivendi, and means that both feature counterfactual assurance. Counterfactual assurance alone gives no reason to prefer public reason liberalism, therefore.

\subsection{The marriage analogy}

Lister motivates his view by giving several examples of other contexts in which we exclude reasons from consideration. As he notes, 'much of social life involves a concern for the reasons on which we base decisions concerning our joint activities' (Lister, 2013: 111), rather than merely the way decisions are made. One example of this is academic appointment decisions. A candidate must show excellence in teaching and research in order to be appointed, but her cat's name does not matter, and is an inappropriate basis for the decision. This example is not useful for Lister's purposes, however. ${ }^{12}$ The reasons that are excluded from consideration here are excluded because all recognise that they are irrelevant to the decision at hand. In contrast, public reason liberalism demands that citizens set aside 
reasons they believe are highly relevant. Are there examples of other contexts where we set aside relevant reasons, for the sake of our relationship with those with whom we are making the decision?

Lister thinks there are, and gives the example of decisions made within marriage (Lister, 2013: 107-8). Jane and Colin disagree on where to send their daughter to school. Jane thinks they are morally permitted to do whatever is best for their child, so can send her to a private school. Their obligations as parents are first and foremost to their daughter. Colin, on the other hand, believes that social justice obligates them to send their daughter to a public school, as long as an adequate one is available. According to Lister, Colin and Jane should respond to this disagreement by bracketing contested considerations, and basing their decision on common grounds. Their commitment to marriage includes a commitment to act in concert on such important matters, and they can serve this purpose by excluding unshared reasons. Colin should agree to not consider the effect their decision has on other children, since Jane considers this irrelevant, because she does not believe that social justice demands that parents take this into account when making decisions that affect their own offspring's welfare. Meanwhile, Jane should agree to not take into account the social advantages their child gets from being part of a club of elite school families, since Colin considers this morally irrelevant. Jane and Colin commit to only considering the benefits their daughter accrues from the intrinsic quality of education at the two schools.

The difference between this and the academic appointment case is that here each party sets aside reasons because the other party considers them irrelevant to the issue, even though they personally consider them to be highly relevant - and perhaps even decisive. For example, Colin believes they have decisive reasons to send their daughter to public school, but agrees to exclude them from consideration because they are grounded in a view of social justice that Jane rejects. He does this not simply to keep the peace, but because it serves his and Jane's joint purpose in marriage. 'In a marriage a commitment to act on shared reasons can be constitutive of a valuable relationship' (Lister, 2013: 108). Lister's model of public reason is analogous to this. 
An initial response one might make to this is that political community is not a marriage. Perhaps there are relevant differences between the kind of relationships we can, and ought, to have with our spouses and our compatriots that make decision-making within marriage an irrelevant model for our decision-making within a political community (see May 2011: $595-8) .{ }^{13}$ Lister (2013: 119-120) believes that 'scaling up' is possible here, because the kind of interpersonal compromise embodied in reason-exclusion in the marriage case can be practised at the level of political community, as his public reason liberalism shows. Some might not be convinced by this, but I will not press this objection here. Instead, I want to question whether Lister correctly identifies the way in which married couples ought to respond to disagreements. If not, then the marriage example cannot support public reason liberalism over argumentative democracy.

According to Lister, Jane and Colin should compromise on reasons, by excluding from their decision-making any reasons that only one of them endorses. An alternative view, however, is that they should compromise on policy, by seeking to find a solution that is somewhat acceptable to both of them. Their marital commitment to joint action can be expressed in this way. Arguably, this enables a more valuable kind of relationship. Rather than demanding that each other exclude reasons that they consider to be highly relevant and very weighty, Jane and Colin can permit those reasons to affect each other's views, while seeking to find a solution they are both happy with. Indeed, if one of them, say Colin, feels particularly strongly about this issue then perhaps Jane would agree to let him have his way here, on the understanding that they will follow her view in cases where she has similarly strong beliefs.

Lister considers this alternative model of decision-making within marriage, by presenting an example from Simon May (2011: 585-6). Ali and Beth disagree on the truth of a religion, and this leads to disagreements on 'whether their children should attend a secular or religious school, how often they should attend church, and so on' (Lister, 2013: 118). May suggests that they might compromise on policy, by sending their children to a secular school, while Beth (the religious parent) also takes them to church each week. They would do so, May (2011: 593-5) argues, because part of what it means to be married is that spouses have 'shared responsibility for ends'. They are each committed to assisting in the realisation of the other's 
ends, modifying their joint activities in light of their individual goals. Despite not sharing Beth's religious beliefs or religious purposes for their children, Ali should recognise that they provide cogent reasons with respect to their joint decisions, because joint responsibility for Beth's ends is part of their marital commitment.

Lister (2013: 119) rightly questions whether spouses should necessarily take responsibility for one another's moral ends. I should certainly care about the realisation of my wife's personal goals, and adjust my own life plans in order to increase her chances of success, even at a cost to my own welfare. But it is less clear that this is true with regard to her moral ends or beliefs, if I consider them deeply mistaken or misguided. It is not clear that Ali, who is an agnostic, can or should see Beth's success in her religious aspirations with regard to their children as an end that they take joint responsibility for. Similarly, Jane cannot internalise Colin's view of social justice or consider it part of her own projects. Neither Ali nor Jane can be expected to adopt ends they disagree with, morally speaking.

Lister might well be right here. Even if so, I do not think we need to accept May's strong conception of shared responsibility for ends in order to favour compromises on policy, rather than on reasons, as the right model of marital decision-making. Ali need not view Beth's religious reasons as part of his own, in the way May proposes. Instead, Ali ought to permit those reasons to shape Beth's view of what they should do, such that those reasons have influence over the final decision via their influence on her, because Ali ought to respect the fact that these are reasons that are very important to Beth. Similarly, Jane need not consider Colin's success in pursuing his understanding of social justice as part of her own purposes or ends. But she should allow that understanding to influence his approach to their joint decision. Spouses should allow all of one another's beliefs and values to shape their individual approaches to issues, engage in open and honest discussion taking all of those reasons into account, and seek a decision acceptable to both on this basis.

Lister suggests that Ali and Beth should instead compromise on reasons, by making the decisions on the 
basis of values they share. ${ }^{14}$ In terms of the schooling decision, they would presumably choose based on the quality of education at the faith and secular schools. Any considerations based on the schools' religious stances would be set aside. For church attendance, Beth could not appeal to the truth of her religion in arguing that their children should attend, but equally Ali could not appeal to his uncertainty about that claimed truth. Instead, they might consider the value of the social opportunities and community that church offers, as opposed to possible alternative activities. In principle, agnostic Ali might believe on this basis that church attendance is justified, while religious Beth might believe that it is not. Whatever decisions they make, however, this approach to their disagreement seems strange. They are deciding on their children's schooling without taking into account one of the major differences between the schools - a difference that will significantly affect their children's experience. Similarly, they are considering whether their children should attend church while ignoring the main reason that most people attend, or don't attend - whether the church's teachings are true or not. However strange, this approach might be justified if it is the only plausible way they could make this decision consistently with their marital commitment to joint action. But it is not; a compromise on policy, which allows Ali and Beth to take into account the full set of considerations they each consider relevant while seeking a solution that is acceptable to both of them, appears much more plausible in this case. Further, many argumentative democrats would consider the strangeness of Lister's model here to be replicated in the public reason liberal demand that all unshared values are excluded from political decision-making.

I do not claim to have provided a full defence of my model of decision-making within marriage, but hope to have cast enough doubt on Lister's model that it cannot provide strong support for public reason liberalism as against argumentative democracy. ${ }^{15}$ The arguments based on alien values and counterfactual assurance also failed to show why argumentative democrats should become public reason liberals, since they failed to demonstrate that the latter view realises a more valuable form of political community than the former.

The usual political liberal response to argumentative democracy is that the enactment of a law that is not 
substantively justified to a citizen fails to respect her as free and equal (for example, Talisse, 2012;

Boettcher, 2007). Even if deliberative democratic procedures have been impeccably followed, if some citizens lack substantive reasons to accept the laws then their moral agency has been disrespected. Lister rules out this response, however. He repeatedly emphasises that his argument for public reason is about what is required for civic friendship, not what is required by respect for persons (Lister, 2013: 59-79, 118). The latter argument seems to me necessary in order to successfully object to argumentative democracy, however. Further, I think that Lister is right in his claim that arguments based on respect for persons most naturally support justificatory liberalism (i.e. the coercion frame of PJP), rather than public reason liberalism.

\section{Tensions within Lister's public reason liberalism}

In the previous section I argued that Lister's justification of public reason liberalism lacks the resources to show why this view should be preferred to argumentative democracy, which does not impose public reason restrictions. In this section I will approach Lister's theory from the other direction, so to speak considering it from the perspective of a political liberal.

I will highlight several tensions and ambiguities within Lister's view that he has not adequately resolved. Further, his responses to them often seem to move his view closer to argumentative democracy. This has two implications. First, it makes it even less clear what value his view realises which argumentative democracy fails to realise. Second, it means that many who are committed to public reason liberalism will find Lister's version of the view unattractive. Further work is needed to better resolve these tensions. My own view is that doing so requires one to endorse justificatory liberalism, rather than public reason liberalism. ${ }^{16}$

\subsection{Zoom}

Lister (2013: 81-103) argues that justificatory liberalism faces what he calls the 'zoom' problem. Whether laws fulfil PJP according to the coercion frame seems to depend on what our level of comparison is. If we 
'zoom in' and apply the unanimous acceptability requirement at the level of particular laws or policies, then little state action will be justified, since each specific law will be rejected by some reasonable citizen. Only an ultraminimal state will be publicly justified. We might therefore 'zoom out', and apply the unanimity requirement to bundles of policies, as against the alternative of having no law on any of these issues. The question is where to stop, however. Presumably even a decidedly perfectionist state would be preferable to having no state at all. The implications of the view, in terms of what laws are permitted, is thus heavily dependent on the way we individuate or aggregate choices. ${ }^{17}$

A similar problem applies to public reason liberalism, however, with regard to the level of specificity at which shared values are defined. There is a set of values that pass the unanimity requirement, because all reasonable citizens accept them. But the precise interpretation of these values, their relative weights, and their application to any specific policy issue, will be controversial (Lister, 2013: 17). Eric thinks that the value of freedom of association is very weighty, and tells in favour of policy $P$, such that $P$ is justified on the balance of public reasons. Deborah rejects the weight Eric puts on this value, however. She thinks that a competing value, such as sexual equality or individual autonomy, outweighs it in this case, such that the balance of public reasons tells against $P$ and favours alternative policy $Q$. For Lister, both $P$ and $Q$ can be legitimately enacted, since Eric and Deborah each believe that their favoured policy is supported by public reason. Their disagreement on the interpretation of the values they are using to assess these policies is nested within their more general agreement on the values themselves. They both appeal to values that they share, despite disagreeing sharply on their implications and relative weights. This 'higher-order unanimity' means that both policies are justified to all citizens, in fulfilment of PJP.

The problem is that whether these policies are supported by public reason largely turns on the level of specificity at which shared values are conceptualised. Lister says very little about how abstract or specific claimed 'shared values' need to be in order to be valid sources for public reasons, but the answer to this question greatly affects the implications of public reason liberalism. ${ }^{18}$ 
Deborah might claim that freedom of association does not even apply to the issue at hand. Eric's interpretation of this value is so misguided that he appeals to it in cases where it is in fact silent. It is implausible to nonetheless claim that Eric's appeal to freedom of association provides a public reason for P. Given that Deborah denies that this value even applies to the issue, it seems doubtful that Eric is really appealing to a value that they share. One could hold one's ground here, and say that as long as Eric sincerely believes that he is appealing to a plausible interpretation of freedom of association this is sufficient for his argument to publicly justify P. This removes any real sense of public reason liberalism ensuring that laws are justified to all citizens, however. It also undermines Lister's claim that laws justified by public reason will not be based on values that some citizens find alien. While Deborah accepts the value of freedom of association, Eric's interpretation of it is completely alien to her.

To truly make decisions on shared grounds we need to agree on more than merely very abstract concepts. The opposite extreme would be to say that all citizens must accept a specific conception of each value, and its relative weight compared to other values, in order for it to be permissibly used within public reason. The obvious problem with this is that the content of public reason would dwindle to nothing. No such highly-specific claims about values will be accepted by every citizen within a polity. Public reason would therefore be radically incomplete; there would be no public reasons bearing on many of the important political decisions that societies need to make. Public reason liberalism would leave us with no substantive basis for lawmaking on these issues. ${ }^{19}$

We need shared values to be defined at a level of generality that allows for a wide range of laws to be justified by appeal to public reasons, but not at such an abstract level that the 'higher-order unanimity' argument becomes implausible..$^{20}$ It is hard to see where the line should be drawn. Rawls's (2005: 446) view is that each citizen should endorse a political conception of justice that all other citizens can recognise as reasonable. My interpretation and weighting of shared values is a valid source of public reasons as long as all other citizens believe that it can be reasonable to accept it. Eric's view of freedom of association fails this test, since Deborah considers it completely implausible. This is still a rather low 
standard, however. Eric could consider Deborah's understanding of shared values minimally reasonable, but also believe it to be deeply mistaken, such that Deborah supports many laws that Eric considers highly unpalatable. We might again question whether these laws can plausibly be said to fulfil PJP.

Lister's specification of shared values appears, if anything, to be more abstract than Rawls's. In his chapter on marriage (Lister, 2013: 135-174), he argues that there are public reasons that support an institution of marriage going beyond the merely contractual. In particular, the public status of a committed, aspirationally life-long, two-person relationship, which comes with a set of legally protected rights and responsibilities, and also imposes legal obligations on third parties, can be supported within public reason by an appeal to the value of intimacy (Lister, 2013: 153-166). ${ }^{21}$ This value must be defined at a very high level of abstraction, such that it is not reasonable to deny that intimate relationships are good. It is unclear what content 'intimacy' has at such an abstract level. It obviously cannot include reference to particular cultures or races. It must allow for both same-sex and opposite-sex relationships to have this value. It also presumably cannot assume that sexual activity is included within the relationship. Indeed, no particular activities, feelings, and modes of attachment within the relationship can be assumed, since the value of any particular aspect of a relationship is likely to be reasonably rejectable.

Given this, it seems implausible to claim that all conceptions of intimate relationships that fit into this highly abstract idea of 'intimacy' provide public reasons. Many appeals to the good of intimacy will appeal to a conception of it that I do not recognise as having much, if any, value. The fact that these appeals are to interpretations of a very abstract value that I cannot reasonably reject does not plausibly mean that they can justify laws to me. I can protest that no public reason has been provided in this case. This might well undermine Lister's appeal to intimacy to justify the public institution of marriage. Whatever conception is required here will be controversial, and the fact that all accept that abstractly-understood, almost contentless, 'intimacy' has value does not make an appeal to this specific conception one that is acceptable to all citizens. 
This 'zoom' issue might not be an insurmountable problem, but it is an unresolved tension in public reason liberalism. In order to get a large range of public reasons, 'shared values' must be defined at a fairly abstract level. This also reduces the moral cost that citizens bear by complying with public reason, since they are more likely to find that their most-favoured policies can be supported by public reasons. But the higher the level of abstraction, the less plausible it is to suggest that appeals to specific controversial interpretations of these values justify policies to everyone. There are therefore pressures in the account both toward lower and higher levels of specificity. Public reason liberal theorists must provide a clear answer as to how they negotiate these pressures, and one that is well-motivated by the basic normative concerns of the view. ${ }^{22}$ Lister has not done so. ${ }^{23}$ What can be gleaned from his examples (such as the marriage case) suggests that he allows an implausibly high level of abstractness in the definition of 'shared values'.

\subsection{Reasonableness and the content of public reason}

Another vital issue is the question of 'reasonableness'. A common objection to political liberalism is that it is self-defeating (Lister, 2013: 124-5; Wall, 2002). In order for PJP to be used as the standard of legitimacy, it must itself be accepted by all reasonable citizens. Yet PJP is reasonably rejectable, making political liberalism self-defeating. ${ }^{24}$ One common response to this objection is to insist that all reasonable citizens in fact endorse PJP. Accepting it is among the criteria for being reasonable. While this rebuts the self-defeat objection, it appears an ad hoc stipulation unless some motivation can be given for this being a necessary condition of reasonableness.

Lister is better able to provide this motivation than many public reason theorists, because of his use of civic friendship as the justification for his view. He argues that civic friendship is experienced as a bilateral relationship among pairs of citizens who share a commitment to justifying laws to one another by appeal to grounds that are acceptable to both of them. Thus, 'I have no reason to care about the acceptability of a reason to people who do not care about qualified acceptability' (Lister, 2013: 127). The kind of community PJP makes possible can only be realised among those who accept PJP, so only those who do so 
are within the justificatory community. Acting on PJP always comes at a moral cost to me, since it requires that I set aside controversial reasons that I believe are sound. This moral cost is only reasonable if others also recognise and act on this duty of restraint.

This is a plausible argument, ${ }^{25}$ but it leaves a vital question unanswered: how we determine what values are accepted by all 'reasonable' citizens, so provide the content of public reason. This is something that Lister is surprisingly unclear on. Many of his examples of public reason arguments, such as in his discussion of marriage, seem to simply rest on an intuitive sense that certain values are acceptable to all.

The interpersonal examples that Lister uses suggest an empirical approach to the content of public reason (Klosko, 2004). In Colin and Jane's case, education is simply a value they happen to both share, the overlap of their respective beliefs and values. We might suppose, therefore, that the shared values within public reason will be whatever values all citizens who endorse PJP happen to accept. Shared values will be the overlap of the comprehensive doctrines endorsed by reasonable citizens within society.

While this seems to be the implication of the marriage example, we might expect Lister to resist it. Rawls is very clear that the content of public reason is not determined by the contingent overlap of presently existing comprehensive doctrines. This would make the theory 'political in the wrong way' (Rawls, 2005: 40). The validity of political principles and values should not depend on existing citizens happening to accept them. ${ }^{26}$ The empirical approach also means that in a less pluralistic society, such as one where everyone endorses certain religious or perfectionist beliefs, public reason would include values that public reason liberals normally consider illegitimate bases for law.

Most public reason liberals therefore hold that public reason's content is determined through a freestanding argument about what values are acceptable to all citizens who both endorse the idea of society as a fair system of social cooperation between free and equal citizens and recognise the fact of reasonable pluralism. ${ }^{27}$ Lister might make a similar claim, but it is not clear how this can be justified within 
his theory. The values that a moral compromise can be based on will be determined by the values accepted by those party to it. In order to have a pre-determined conception of the shared values that constitute public reason, Lister must claim that all citizens who endorse PJP, so seek to justify laws using reasons that all who endorse PJP can accept, must also accept this pre-determined set of values. It is not clear why this would be the case, however. The empirical approach to the content of public reason seems to fit better with the civic friendship justification, but most public reason liberals consider it objectionable.

Lister might respond to this by arguing that the value of friendships, including civic friendships, depend on objective standards as well as on subjective attitudes. For example, the value normally associated with a loving friendship is diminished if the parties love each other for being committed fascists. ${ }^{28}$ Civic friendship is similar; its value depends on citizens sharing and acting on certain values, and not on others.

This reply can only get us so far, however. It might well be true that citizens cannot realise valuable civic friendship when they act on certain, morally objectionable, values. More specifically, certain values are incompatible with PJP, and thus with the ideal of civic friendship that grounds PJP. No-one who believes that political power should be exercised in ways it is reasonable to expect others to accept could also endorse fascist values. Such values therefore cannot be shared values among reasonable citizens, so cannot be sources of public reasons. They are incompatible with the core political liberal claim. This shows that Lister's view need not be fully empirical; certain values are excluded from public reason by the fact that they are incompatible with the ideal of civic friendship that underlies PJP.

Many religious and perfectionist values are not objectionable in this way, however. They can be endorsed by citizens who accept PJP. There is no reason to think that decisions based on these values cannot realise (valuable) civic friendship, if such values happen to be accepted by all parties to the agreement, and all show a willingness exclude from their decision-making values over which they disagree.

If Ali and Beth agreed on the truth of a particular religion, then they can realise the good of acting in 
concert within their marriage by making decisions on the basis of that religion. Similarly, Jane and Colin could realise that good if they acted together based on a shared conception of social justice. The same applies to civic friendship. If all reasonable citizens within a particular society endorse religious or perfectionist value $\mathrm{V}$, then those citizens can achieve relations of civic friendship by acting together based on $\mathrm{V}$. The fact that value $\mathrm{V}$ could be rejected by citizens who endorse PJP is irrelevant, since in this society it is in fact a value that all such citizens accept. Moral compromise is not needed with non-existing reasonable views, and it is moral compromise that constitutes citizens' relationships as ones of civic friendship (Lister, 2013: 117-118). This is the sense in which the content of public reason within Lister's account must be empirical, and could include values that political liberals normally consider inappropriate grounds for political action.

\subsection{Conflicts of loyalty}

There might be times when citizens who are generally committed to public reason liberalism believe that on a certain issue the moral cost it involves is too great, so they must advocate for laws on this issue on the basis of their pressing comprehensive reasons. There will be some sacrifices of (what they consider to be) true justice that citizens are unwilling to make. Lister $(2013,129)$ admits that in some cases such violations of the duty of civility for the sake of true justice might be justified, ${ }^{29}$ and rightly insists that this does not undermine his general justification for public reason. Civic friendship is still possible as long as citizens are generally willing to bear the moral cost of remaining within the confines of public reason.

I think this is the right public reason liberal approach to 'conflicts of loyalty'. It raises the worry, however, that cases of citizens violating public reason on comprehensive grounds might occur frequently, such that the exception becomes the norm. ${ }^{30}$ If citizens are permitted to weigh the values realised through the use of public reason against values that provide countervailing reasons on a case-by-case basis then they might often judge the latter to be weightier. Arguably, Lister's specific justification for public reason makes this more likely. Civic friendship might be seen as a less weighty value than the demands of respect for persons, such that public reason requirements are more easily overridden if grounded in the former 
than in the latter. ${ }^{31}$ This is particularly the case in light of my argument in Section 3 that citizens can still achieve valuable relations with one another - and even civic friendship, as Lister understands it - without offering public reasons.

This would be less of a concern if conflicts of loyalty were themselves infrequent. Lister might appeal to his 'zoomed out' understanding of the shared values that constitute public reason in order to argue that such conflicts will be rare. Citizens are likely to find some plausible interpretation and balance of those values to support many of their most-preferred laws, or at least laws close to them, given that the values themselves are defined at such a high level of abstraction. The moral cost demanded by public reason restrictions will rarely be very great.

To the extent that this is true, however, it threatens to make public reason restrictions fairly vacuous, with almost any law having some putative public reasons in its favour. This will make Lister's view less attractive to many public reason liberals. It also reduces the distance between public reason liberalism and argumentative democracy. I suggested that Lister's main objection to argumentative democracy would be that it allows laws to be enacted that are justified by unshared values, which many citizens find alien. This objection applies with similar force to Lister's own view, given the abstract nature of the 'shared values' in his theory. This reinforces my argument that Lister had not shown why (his) public reason liberalism is preferable to argumentative democracy.

The most obvious response to this would be to 'zoom in', and define shared values at a lower level of abstraction. This will make conflicts of loyalty more common, however, so might lead to citizens frequently judging that the duty of civility is overridden by countervailing values, such as the demands of ideal justice, especially if that duty is grounded in civic friendship rather than respect for persons. This would itself undermine public reason liberalism. Many citizens would act politically on the basis of non-public reasons, laws would be enacted that do not fulfil PJP, and the polity would not realise the values that public reason liberalism claims to achieve. 


\section{Conclusion}

Lister has made an important contribution to the ongoing debate over public reason, due to his distinct justification for public reason requirements. This justification leads to a view that is different from mainstream public reason liberalism in several important respects. It is better able to deal with certain common objections to the view, but has implications that many who are committed to PJP would find objectionable. In particular, it seems to lead to an empirical understanding of the content of public reason, and to allow for almost any law to be justified by public reasons. Lister's view also reduces the gap between public reason liberalism and argumentative democracy. Those who reject the former in favour of the latter are given little reason to change their mind, especially given that Lister's arguments from civic friendship are unpersuasive.

The tensions I have highlighted in Lister's view - as well as others I have lacked space to discuss ${ }^{32}-$ recur for all public reason liberal views. More work is therefore needed both to demonstrate the superiority of political liberalism to argumentative democracy, and to better deal with these tensions. The solution, in my view, is to embrace justificatory liberalism rather than public reason liberalism. This provides new resources to object to argumentative democracy, and dissolves or resolves many of the problems with public reason liberalism. Arguing for this claim will have to await another day. ${ }^{33}$

\section{Notes}

1. An anonymous reviewer rightly pointed out to me that Gaus in some ways distances himself from the coercion frame in his recent work, since he argues that justificatory liberalism centrally concerns the authority of laws, and of moral demands more generally, rather than the legitimacy of coercion. This is particularly clear in Gaus (2014). Nonetheless, Gaus (2011: 341-356, 479-490) still ultimately endorses a right against coercion, such that all coercive laws must be acceptable to all reasonable citizens, so I think Lister is right to associate Gaus with the coercion frame. 
2. This can be seen in Gaus and Vallier (2009). They accept convergence justifications, due to endorsing the coercion frame.

3. Lister (2013: 59-103) criticises justificatory liberalism in some depth. I note two of these objections in Section 4.1.

4. Lister (2013: 29-70) rejects these putative justifications for political liberalism, while also arguing that a variety of standard objections that appeal to these values do not succeed. Lister thus claims that debates over these other values are distinct from debates over public justification and public reason.

5. Lister calls this a case of 'consensus without convergence'.

6. This term was suggested to me by Stuart White. Christiano (2009) defends a similar view, which he calls 'wide deliberative democracy', in contrast to 'narrow deliberative democracy', which includes public reason restrictions.

7. This is particularly the case given the issues I discuss in Section 4, which show that talk of 'shared values' is more complicated than it seems.

8. This does not necessarily mean that violations of public reason restrictions can never be justified. Lister acknowledges that they can be, as I note in Section 4.3. The argument is simply that relationships between citizens are less valuable when citizens fail to offer public reasons.

9. Andrew Lister pointed out to me that some arguments for argumentative democracy might not require citizens to have the commitments and attitudes I have argued enable them to realise civic friendship. This might well be true. However, just as Lister claims that the best argument for public reason liberalism does involve these commitments, my claim here is that the same is true for argumentative democracy. It is certainly true in the views presented by Wolterstorff and Eberle.

10. This kind of open engagement is also permitted within a public reason liberal society, of course. It is not incentivised or encouraged in the way that it is within argumentative democracy, however. Within argumentative democracy, deliberative engagement with other citizens' full sets of reasons might well be necessary in order to persuade them to vote in particular ways, and thus to achieve legislative majorities. This is not the case within public reason liberalism, since comprehensive 
reasons should not influence citizens' votes, or political outcomes, so are not politically salient in the same way.

11. Indeed, even if we understand civic friendship differently, and hold that some stronger form of civic friendship is achieved under public reason liberalism, given the focus on shared values and the additional sense in which alien values are not pursued, the considerations in this section suggest that further argument would still be needed to show why Lister's view is all-things-considered better as a model of citizenship.

12. And Lister never claims that it is. He uses it as one familiar example of restrictions on reasons for decisions, along with others such as courtroom decisions, when discussing the different roles such restrictions can play in social life (2013: 111).

13. Rawlsians might also consider this the wrong kind of argument to justify public reason, since it involves appeal to the non-political value of (non-civic) friendship, as an anonymous reviewer pointed out to me.

14. An anonymous reviewer commented that Lister presumably also believes that the shared values and reasons must meet some objective standards in order to be valid bases for Ali and Beth's decision. Lister hints at this by talking about the parties to decisions believing that one another's views are 'reasonable'. This point relates to my discussion in Section 4.2.

15. My own model might be attractive to proponents of argumentative democracy, since it has clear similarities with that view. As Lister pointed out to me, however, it might suggest that we should require some kind of political commitment to compromise on policy, barring majorities from simply enacting their ideal policy in the face of strong minority dissent. This would be an amendment to argumentative democracy, as I have presented it. If proponents of argumentative democracy wished to resist this implication, they might follow May in denying that marriage is an appropriate model for political decision-making.

16. I lack space to defend this view here, however.

17. This issue is closely related to that of incrementalism, which concerns whether or not every extra increment of coercion must be accepted by every citizen. In other words, is a less coercive policy 
automatically publicly justified rather than a more coercive one, if some citizens prefer the former? Lister argues that an affirmative answer is the most natural interpretation of justificatory liberalism, but Gaus rejects this. Further, Lister claims that the best response that justificatory liberals can give with regard to zoom should also commit them to incrementalism, since the basic logic is the same. However, this raises the 'libertarian dictator' objection: justificatory liberalism would have ultra-minimal state, or even anarchistic, implications. For replies, see Gaus (2010: 195-206).

18. Lister (2013: 81-103) argues that a central problem with justificatory liberalism it is that its implications depend on some rather technical issues with regard to its specification. The same is true for public reason liberalism, however.

19. For discussion of the issue of completeness within public reason liberalism, see Schwartzman (2004).

20. Lister (2013: 102) recognises this problem, but it is not clear how he resolves it. Little light is shed by the discussion at Lister (2013: 131-2).

21. Among other values. Intimacy plays a vital role within Lister's argument.

22. The zoom problem could be deeper than this, however. Lister (2013: 98-101) argues that his objections to justificatory liberalism show that there will be controversy over whether laws are publicly justified, and that this will undermine the authority of law. If this is correct, then the same might be true for public reason liberalism, especially for versions that are grounded in respect for citizens' moral freedom and equality. Disputes between citizens over the level of abstraction at which shared values can plausibly be defined will lead to disagreements over what laws are publicly justified. Even if a law's advocates believe it to be justified by shared values, if I believe they are mistaken about this then I can claim that my moral status is being disrespected, and deny the authority of the enacted law.

23. Quong (2011: 180-7) can provide a more plausible response to this tension, since on his account all public reasons can be traced back to being interpretations of three general liberal principles. This relies on a controversial reinterpretation of the overlapping consensus, however. For criticism, see Zoffoli (2012).

24. It is worth noting that Lister claims that this objection does not apply to justificatory liberalism, only 
to public reason liberalism. For a contrary view, see Wall (2013).

25. Although it presupposes that Lister's civic friendship justification for public reason liberalism is successful, which I disputed in Section 3.

26. Quong (2011: 145-153) objects to what he calls the 'external conception' of political liberalism on this basis.

27. This has led some (such as Bohman and Richardson, 2009) to argue that the idea of 'reasons that all can accept' ceases to play any role in the theory, since all the work is done by the conception of reasonableness. Lister (2013:25-7) replies to this objection.

28. I owe thanks to an anonymous reviewer for suggesting this reply and example.

29. In this he follows Ebels-Duggan (2010). Rawls arguably hints at a similar response in his discussion of full justification (2005: 386-7) and in his repeated claim that political values normally outweigh competing values (2005: 138, 154-8, 392).

30. Lott (2006) makes this claim with respect to Rawls's theory.

31. C.f. Boettcher's (2012: 164-5) concern that construing public reason requirements as role-based duties associated with citizenship would undermine their overriding nature.

32. These include questions around the extent to which comprehensive doctrines can permissibly influence citizens' understandings of the shared values within public reason, and the way in which the 'unreasonable' are treated.

33. And would have to involve responding to the forceful objections that Lister presents.

\section{References}

Boettcher JW (2007) Respect, recognition and public reason. Social Theory and Practice 33(2): 223-249.

Boettcher JW (2012) The moral status of public reason. The Journal of Political Philosophy 20(2): 156-177. Bohman J and Richardson HS (2009) Liberalism, deliberative democracy, and "reasons that all can accept". The Journal of Political Philosophy 17(3): 253-274.

Christiano T (2009) Must democracy be reasonable? Canadian Journal of Philosophy 39(1): 1-34. 
Ebels-Duggan K (2010) The beginning of community: Politics in the face of disagreement. The Philosophical Quarterly 60(238): 50-71.

Gaus G (2009) The place of religious belief in public reason liberalism. In: Dimovia-Cookson M and Stirk PMR (eds) Multiculturalism and Moral Conflict. London: Routledge, pp. 19-37.

Gaus G (2010) On two critics of justificatory liberalism: A response to Wall and Lister. Politics, Philosophy and Economics 9(2): 177-212.

Gaus G (2011) The Order of Public Reason: A Theory of Freedom and Morality in a Diverse and Bounded World. Cambridge: Cambridge University Press.

Gaus G (2014) The good, the bad, and the ugly: three agent-type challenges to The Order of Public Reason. Philosophical Studies 170(3): 563-577.

Gaus G and Vallier K (2009) The roles of religious conviction in a publicly justified polity: The implications of convergence, asymmetry and political institutions. Philosophy and Social Criticism 35(1-2): 51-76. Greenawalt K (1988) Religious Convictions and Political Choice. New York: Oxford University Press. Klosko G (2004) An empirical approach to political liberalism. In: Young SP (ed) Political Liberalism: Variations on a Theme. Albany, N.Y.: State University of New York Press, pp. 129-148.

Lister A (2013) Public Reason and Political Community. London: Bloomsbury Academic.

Lott M (2006) Restraint on reasons and reasons for restraint: A problem for Rawls's ideal of public reason. Pacific Philosophical Quarterly 87: 75-95.

May SC (2011) Moral compromise, civic friendship, and political reconciliation'. Critical Review of International Social and Political Philosophy 14(5): 581-602.

Quong J (2011) Liberalism Without Perfection. Oxford: Oxford University Press.

Rawls J (2005) Political Liberalism, expanded edition. New York: Columbia University Press.

Schwartzman M (2004) The completeness of public reason. Politics, Philosophy \& Economics 3(2): 191-220.

Schwarzenbach SA (1996) On civic friendship. Ethics 107(1): 97-128.

Schwarzenbach SA (2005) Democracy and friendship. Journal of Social Philosophy 36(2): 233-254. 
Talisse RB (2012) Religion, respect and Eberle's agapic pacifist. Philosophy and Social Criticism 38(3): 313-325

Wall S (2002) Is public justification self-defeating? American Philosophical Quarterly 39(4): 385-394.

Wall S (2013) Public reason and moral authoritarianism. The Philosophical Quarterly 63(250): 160-169.

Wolterstorff N (2012) Liberal democracy as equal political voice. In: Wolterstorff N and Cuneo T (ed)

Understanding Liberal Democracy: Essays in Political Philosophy. Oxford: Oxford University Press, pp.

113-142.

Zoffoli E (2012) The place of comprehensive doctrines in political liberalism: On some common misgivings about the subject and function of the overlapping consensus. Res Publica 18(4): 351-366. 